\title{
INTERACTION BETWEEN CONSUMER LAW AND COMPETITION LAW IN PANDEMIC TIMES ${ }^{1}$
}

\author{
Olesea Plotnic, PhabD., Professor Jean Monnet \\ Moldova State University, Law Faculty \\ General Secretary, Legal Culture Association „Henri Capitant” \\ Chișinău, Republic of Moldova \\ plotnicolesea.aum@gmail.com
}

\begin{abstract}
If in the case of consumer law, as protected persons are the consumers, then in the case of competition law, the protected entities are the competitors.

A combination of actions in competition law presupposes that the same commercial offer satisfies several individual interests of consumers. In the strictest sense, such a combination implies the same legal fact, simultaneously opening up more possibilities for the consumer to choose due to loyal offers from a professional, if he is monopolistic or dominant in the market. More broadly, it can also be accepted that offers can be combined from several competing professionals relating to the same product or service and concerning the same individual interest of a consumer.
\end{abstract}

The possible complementary effects of common law, which would justify the non-limitation of a specific piece of legislation, can never lead to a new monopoly. In some cases this will make competition law more effective and, in other cases, provide marginal and non-exclusive protection to consumers who do not have a direct right guaranteed by competition law.

The purpose of this article is to demonstrate the interdependent relationship between competition law and consumer law, from the perspective that both have the same common goal, namely to limit abuses by professionals in their economic activity, especially during pandemic times.

Keywords: competition, consumer, Covid-19, unfair competition, liability, damage, protection.

This article was developed within the project Jean Monnet Support to Associations in European Integration and Intellectual Property Protection Studies / EUPROIN, no. ref. 611344-EPP-1-20191-MD-EPPJMO-SUPPA, implemented with the financial support of the Erasmus+ program of the European Union. "The support provided by the European Commission for the development of this publication does not constitute an endorsement of the content, which reflects the views only of the authors, and the Commission cannot be held responsible for any use which may be made of the information contained therein." 


\section{INTRODUCTION}

Competition and consumer protection represent the quintessence of the market economy, on the one hand in the case of competition the protected entities are the consumers, and on the other hand in the case of the consumer right, as protected we have the consumers. Respectively, competition means the consumer's choice of several alternatives of products or services offered.

Where there is competition, a more efficient allocation of resources is achieved, as the producer constantly monitors the relationship between them and costs, and at a competitive quality and price for the consumer in a market based on fair competition. However, the producer does not influence the market alone, but only through competitive relations with other producers, which always lead to a decrease in prices and, implicitly, to market diversification by stimulating purchases. $^{2}$

The concept of "competition" is a set of relationships between professionals resulting from their desire to offer the consumer the best possible price, thus ensuring a better place in the market. It should be noted that the phenomenon of competition is naturally linked to the consumer's freedom of choice, competition being the most important regulatory force on the market economy. Inseparably, any product and/or service has as final destination the consumer, who can be any natural person who procures, benefits from the product and/or services for purposes not related to the entrepreneurial activity. ${ }^{3}$ The given notion of the national consumer was perfectly transposed by the Republic of Moldova from the European Union Directives. ${ }^{4}$

Competition is an inherent feature of a market economy, based on free initiative generated by private property. Moreover, it can be said that the mechanism of any true market economy is a competitive one. A competitive and healthy market leads to increased productivity and competitiveness, lower prices and costs, and innovation. In the Republic of Moldova, only a few years ago the foundations of a systemic competitive environment began to be laid. Due to the decades in which there was a total lack of a market economy, the process of adapting and learning

2 Fugaru C. Anti-competitive practices and antitrust policies in the European Union. In: Journal of the Faculty of Economics and Business Administration West University of Timisoara, 2006, p.110

3 art.1 of the Law on consumer protection no.105-XV from 13.03.2003 of the Republic of Moldova, Official Gazette no.126-131/507/2003

4 Council Directive 2011/83 / EU on consumer rights, amending Council Directive 93/13 / EEC and Directive 1999/44 / EC of the European Parliament and of the Council and repealing Directive 85/577 / EEC of the Council and Directive 97/7 / EC of the European Parliament [2011] OJ L $304 / 2011$ 
new values was difficult and too long. The Constitution of the Republic of Moldova provides in art. 9 para. (3) that the market, free economic initiative, and fair competition are the basic factors of the economy. Moreover, according to art. 126, the Republic of Moldova economy is a market economy, socially-oriented, based on private and public property, engaged in free competition, and the state must ensure fair competition ${ }^{5}$.

In the context of the obligations assumed by the Republic of Moldova under the Partnership and Cooperation Agreement between the Republic of Moldova and the European Union ${ }^{6}$, as well as the Moldova-EU Action Plan ${ }^{7}$ it was necessary to develop a legislative framework to promote economic development by improving the investment climate. ensuring non-discriminatory conditions for conducting business. This implies, by implication, an adequate legislative framework in a liberalized economy and a fair competitive environment. The adjustment of the competition law of the Republic of Moldova took place over several years, with external assistance. It seems that Moldova has made progress compared to other countries in the region. However, further efforts are needed to complete the reforms that are already underway. The culmination of the efforts of the specialists from the Republic of Moldova in the field of competition law, of the competition authority, and the support of foreign experts was represented by the elaboration and adoption by the Parliament of the Competition Law no. 183 from 2012. ${ }^{8}$

Although some consider that the very detailed provisions of the law should be reflected in the secondary legislation, such as regulations and internal guidelines, this normative act is an innovative one for the Republic of Moldova and faithfully transposes the provisions of art. 101-106 of the TFEU9 ${ }^{9}$ and other secondary European provisions, a fact confirmed by the Joint Document of the European Commission on the progress of the Republic of Moldova in implementing the European Neighborhood Policy of $2013^{10}$ which states that competition law "is well aligned with EU rules”. We must recognize that Competition Law no. 183/2012 is one of the most progressive pieces of legislation because it introduces new atti-

5 Constitution of the Republic of Moldova. Official Gazette of the Republic of Moldova, No.1/1994

6 Partnership and Cooperation Agreement between the European Communities and the Republic of Moldova, signed in Brussels on November 28, 1994, ratified by the Decision of the Parliament of the Republic of Moldova, No. 627 [1995] OJ L 181, pp. 0003 - 0048.

7 Republic of Moldova - European Union Action Plan for the period 2005-2007, International Treaties No.38/2006

8 Competition law of the Republic of Moldova no. 183/2012. Official Gazette No.193-197/2012

9 Article 10 (1) TEU (Lisabon)

10 European Commission Joint Staff Working Document Implementation of the European Neighbourhood Policy in Republic of Moldova: Progress in 2012 and recommendations for action. SWD, 2013, No. 80 final, 20 p. 
tudes, procedures, and mechanisms, which will have to be dealt with by the Competition Council. Moreover, the recent conclusion of the Association Agreement, ${ }^{11}$ which incorporates provisions of the deep and comprehensive free trade area with the European Union, marked an important point in the trajectory of European integration of the Republic of Moldova. This agreement will provide an important basis for mutual trust in trade relations between the EU and the Republic of Moldova, along with specific benefits for Moldovan businesses and consumers in the market economy. But it also imposes, at the same time, scientific research on the content of the obligations assumed by the Republic of Moldova, obligations reflected in the Competition Law no. 183, adopted in 2012. To this end, legal professionals, the competition authority, as well as businesses and consumers, must be familiar with European Union law and practice on prohibited activities, such as horizontal anti-competitive agreements, existing leniency policies. , etc.

The COVID-19 pandemic has caught every person medically and economically unprepared, and the governments of each country have found it difficult to manage the medical equipment crisis, the economic crisis that has stopped production, circulation, etc. Respectively, to avoid making the same mistakes, people have to learn from the mistakes made at the beginning of the pandemic. One of the weaknesses in which some countries proved to be completely unprepared was the fair competition and consumer protection sector. The simple examples from which such conclusions can be drawn are the price of masks and hand sanitizer at the beginning of the pandemic that was produced in small batches but began to be requested en masse by all countries, being essential in these difficult times. The law of the market acted according to the situation, the increase in demand induced the increase in the price of the product and it is not necessarily an obvious negative law. Thus, due to the unpreparedness of these state agencies, consumers themselves proved able to buy a box of disposable masks of 50 pieces at a price $600 \%$ above the price that this box had before the pandemic. Some examples can be found in the following countries: France a box of 50 pieces could be bought for 3 euros before the pandemic and 16 euros during the pandemic, Italy the same box that cost 2.5 euros before the pandemic could be purchased by 12 euros a few months after the beginning of the pandemic. ${ }^{12}$

11 Association Agreement between the Republic of Moldova and the European Union, No. 112/2014. Official Gazette, No.185-199/2014

12 Sagan, A., Mask makers raise prices as material, labour costs rise amid pandemic, June 2020 [https://www.mromagazine.com/2020/06/15/mask-makers-raise-prices-as-material-labour-costs-rise-amid-pandemic/], Accessed 5 April 2021 
From our point of view, an important role in society should have the state, which must act promptly and effectively enforce competition law concerning consumer protection, in the context of the emergency that has been established in all countries, and it is necessary to establish a close link between consumer demand and supply offered by professionals in conditions of a pandemic product crisis.

\section{THE EUROPEAN SCIENTIFIC APPROACH TO THE RELATIONSHIP BETWEEN CONSUMER PROTECTION LAW AND COMPETITION LAW.}

In a liberal vision of the market economy that flourished in the nineteenth century and is now widely taken up by the European authorities, competition is to the benefit of consumers ${ }^{13}$. Competition policy aims to enforce rules to ensure that companies compete fairly with each other. It helps to stimulate entrepreneurship, innovation and productivity: it makes it possible to broaden the offer for consumers by improving the quality of products and services while ensuring a reduction in prices, and in particular: ${ }^{14}$

a) Low prices for all: The easiest way to gain market share is to offer a better price. In a competitive market, prices are pulled down. This is an advantage for consumers, but not only: companies are encouraged to produce if more people can afford to buy their products, which stimulates the whole economy.

b) Better quality: Competition also provides an incentive for companies to improve the quality of the products and services they sell to attract more customers and increase their market share. Quality can mean that: products that last longer and work better; more efficient after-sales or breakdown services; a better welcome from the customer.

c) More choice: In a competitive market, companies seek to distinguish their products from others. For the consumer, this means more choice and the possibility of opting for the value for money that best suits him.

d) Innovation: To offer this choice to consumers, and to produce better, companies must be innovative - from product design to production techniques to the services offered.

e) Stronger in the face of global competition: Competition within the EU helps European companies to be more competitive in the rest of the world and to withstand international competition.

13 Paisant, G., Droit de la consommation, ed. Themis droit, PUF, Paris, 2019

14 Commission European, act for the Consumers. Why is competition policy important for consumers? [https://ec.europa.eu/competition-policy/consumers/why-competition-policy-important-consumers_ fr], Accessed 20 June 2021 
There is no doubt that these goods are recognized as competition only to the extent that it is regulated to be exercised in a fair and untrue manner, in particular employing company agreements. In its circumstances, as was noted before the appearance of the first laws specially devoted to the protection of consumers at the beginning of the 1970 s, this protection is a natural matter for competition law. ${ }^{15}$

Consumer law, concerning competition law, then presents itself as a right called upon to regulate the function of consumption ${ }^{16}$ or, from a more legal point of view, as the set of rules applicable to relations between consumers. and profession$\mathrm{als}^{17}$. However, this view cannot be accepted, since it presupposes, among other things, the apprehension of almost all common law of contracts and therefore a disproportionate enlargement of consumer law. ${ }^{18}$

In general, it has been shown that the rules which aim to develop competition must be regarded as serving the interests of consumers, in that they provide them in principle with the lowest price and the best value for money ${ }^{19}$. More specifically, it has emerged that certain provisions concern both competition law and consumer law. These are the rules applicable to fraud and counterfeiting, the regulation of various forms of sale such as the prohibition of the so-called "snowball" sale, the rules on pricing, the obligation to inform on prices and conditions of sale, etc. ${ }^{20}$

As mentioned above, the final beneficiaries of competition are consumers of goods and/or services, which require special protection by establishing protective regulations and effective mechanisms that would balance the interests of both parties: on the one hand consumers, as vulnerable parties, and on the other hand professionals, strong parties to compete loyally in the market to create a competitive offer to end consumers. From this perspective, it is interesting to establish from a scientific point of view, the general interest of competition law as the lowest common denominator of the particular interests of consumers.

\footnotetext{
15 Hémard, J., Droit de la concurrence et de la protection de certains consommateurs Gaz. Pal. 1971, 2, doctr. 575

16 Cas, G., et al., Traité de droit de la consommation, PUF, 1986, p.78.

17 Calais-Auloy, J., et al., Droit de la consommation, 5 éd., Dalloz, 2000, p.145.

18 Py, P., Droit du tourisme, Dalloz 15 Novembre 1996, p.216

19 Hémard, J., Droit de la concurrence et protection des consommateurs, Gaz. Pal. 1971, 2, doctr. 575, p. 19

20 Oppetit, B., L'expérience française de codification en matière commerciale, D. 1990, chr. 6, note 21, p.88
} 
According to the French author, J.J. Rousseau's, ${ }^{21}$ general interest can be treated as a paradox. Such a notion poses, moreover, a problem of definition, because the terms of interest and generally seem to be incompatible, which continue to lead to the delimitation of competition law, which promotes a general object and the consumer's right covering a personal, individual purpose, unrelated to professional activity. Respectively, the interest of an individual means what is profitable, advantageous to him. Each one subjectively defines who is interested in him, depending on his tastes, desires, the social and financial situation. There are as many interests as there are individuals. The interstellar is therefore presumed to belong to the sphere of the subjective, the particular. ${ }^{22}$ However, there is a possibility to give a meaning to the notion of general interest, by researching the realization of individual interest from the perspective of the ultimate goal of competition law, to offer products and services at a price, competitive quality on the market, whose final beneficiaries are individuals, individuals.

Therefore, these two parallels of the general interest and the individual interest find a point of consensus since several individual interests of different individuals coincide and respectively create a demand for common interest by guts, style, color for the subsequent generation of offers of interest. general competition from the market.

\section{LIABILITY FOR DAMAGE CAUSED IN THE EVENT OF UNFAIR COMPETITION}

According to art.77 of the Competition Law of the Republic of Moldova, "the commission of acts of unfair competition prohibited in art.15-19 of this law is sanctioned by the Competition Council with a fine of up to $0.5 \%$ of the total turnover achieved by the undertaking concerned in the year preceding the sanction. The damage caused as a result of the actions found as unfair competition is to be repaired, following the provisions of the Civil Code, by the company that caused it". ${ }^{23}$

According to the respective norm, it results that the Moldovan legislator offers the possibility to the person prejudiced by the actions of unfair competition of a professional to address to the Competition Council to prohibit and sanction the author of the unfair competition act, in the perspective of addressing in court to

\footnotetext{
${ }_{21}$ Rousseau, J.J., Les Integrales de Philo, Du contrat social, Livres I a IV, notes et commentaires de J.F. Braunstein, Nathan, Paris, 2002, p.177

22 op.cit., p. 177

23 Competition law of the Republic of Moldova no. 183/2012. Official Gazette No.193-197/2012
} 
repair the damage following the provisions of the Code of Civil Procedure and the Civil Code, the action being called "action in unfair competition".

Even if, as mentioned above, the final beneficiary of competition is the consumer as an individual, it must be borne in mind that a precondition for action in unfair competition is that the act giving rise to liability be an act of competition, an act committed in a competition report. This means that the parties must be traders, address the same customers or their field of activity be identical or similar. In this sense, according to art.80 paragraph (5) of the Competition Law of the Republic of Moldova "The right to the action in unfair competition belongs to natural and legal persons practicing entrepreneurial activity, provided that there is a relationship between them and the perpetrator competition, ie to exercise an identical or similar kind of activity". The existence of this rule is restrictive, offering limited consumer protection in the case of counterfeit products, which can cause injury due to unfair competition through dishonest actions, being deprived of the quality and safety of products, including compensation for damage caused. According to European judicial practice, anyone can claim compensation for the damage suffered, where there is a causal relationship between the damage suffered and an agreement or practice prohibited under EU competition rules ${ }^{24}$.

The Moldovan legislator establishes the general rule of liability for unfair competition actions stipulating that: the court will oblige the person committing an unfair competition action to cease the action or to remove the consequences, to return the confidential documents illegally appropriated from their rightful holder and, after case, to pay compensation for the damages caused, according to the legislation in force ${ }^{25}$.

In a narrow sense, the injury consists in the removal or loss of customers and, consequently, in the decrease of sales and, implicitly, of the turnover ${ }^{26}$, although in a broad sense the damage caused by an unfair competitive act may directly affect the economic interests of consumers. cases the burden of proof is on the plaintiff, and the assessment and reparation are determined at the discretion of the trial court ${ }^{27}$.

24 Case C-360/09 Pfleiderer, Rep., [2011], p.I-5161, par. 28; Case C-199/11 European Community / Otis NV and others, [2012], par. 43

25 Competition law of the Republic of Moldova no. 183/2012. Official Gazette No.193-197/2012

26 Castravet,, D., Damage - an essential condition of tortious civil liability in matters of unfair competition, "National Law Review", 2016, no.11, p.58

27 Plotnic, O., et al., Conceptions actuelles en matière des droits intellectuels en cumul avec la concurrence déloyale, Droit, humanité et environnement, Mélanges en l'honneur de Stéphane Doumbé-Billé, 1 re édition Larcier (France), 2020, p.249-262 
The exact calculation of the damage caused by the illicit deeds is, together with the demonstration of the causal link between it and the tort deed, one of the most difficult steps in the cases concerning the compensation of the victims of the anticompetitive deeds. Accurate calculation of damages is, of course, a common problem in any case of tortious civil liability. The lack of legal criteria for assessing the damage further complicates the activity of the competent court leaving room for inaccuracy and ambiguity. ${ }^{28}$

At the European Union level, unfair competition is governed by Directive 2005/29 / EC of the European Parliament and of the Council of 11 May 2005 concerning unfair business-to-consumer commercial practices in the internal market. ${ }^{29}$ The directive defines commercial practices prohibited in the European Union (EU). The Directive also protects the economic interests of consumers before, during, and after a commercial transaction. Unfair commercial practices covered by Directive 2005/29 / EC are practices which: do not comply with the requirements of professional diligence and are likely to significantly distort the economic behavior of the average consumer.

Compensation in competition matters is also the subject of Directive 2014/104 / EU of the European Parliament and of the Council of 26 November 2014 on certain rules governing actions for damages under national law in the event of infringements of the competition laws of the Member States. and the European Union. ${ }^{30}$

The imperative nature of Directive 2014/104 / EU is based on its basic purpose that, whether a natural person, including consumers and businesses, or a public authority - any person has the right to bring an action for damages before national courts. This was caused by an infringement of the competition rules. And according to the case-law of the Court of Justice of the European Union (Court of Justice), any person can claim compensation for the damage suffered if there is a causal relationship between that damage and an infringement of competition law.

The European Commission issued in 2013, after a long period of study and analysis, a guideline regarding the assessment by the parties to an action in claims for damages caused by anti-competitive acts and by the competent courts, of the

28 op.cit., p. 250

29 Council Directive 2005/29 / EC on unfair business-to-consumer commercial practices in the internal market and amending Council Directive 84/450 / EEC, Directive 97/7 / EC, 98/27 / EC and 2002/65 / EC [2005] OJ L 149/22

30 Council Directive 2014/104 / EU on certain rules governing actions for damages under national law in the event of infringements of the competition laws of the Member States and of the European Union [2014] OJ JO L 349 
amount of these damages. These are the "Commission Communication on the quantification of damages in actions for damages alleging infringement of Article 101 or 102 of the Treaty on the Functioning of the European Union" and the "Practical Guide to the quantification of damages in actions for damages based on infringements of Articles 101 and 102 TFEU". ${ }^{31}$

The role of the practical guide is to provide information that can be used in national legal practices and rules, not to replace them. Although it does not have binding force, it is a very useful working tool, of 70 pages full of concrete aspects and even examples of calculating such damages, a very good synthesis of the literature and practical cases so far pending before the courts in Europe and the USA. The quantification of injury in competition law cases is significantly limited, by its very nature, in terms of the degree of certainty and accuracy that can be expected. ${ }^{32}$

The application of interest is an essential component in awarding compensation. As the Court has pointed out, full compensation for the damage suffered must include reparation for the adverse effects which have elapsed in the time since the damage caused by the infringement. These effects are monetary depreciation and the fact that the injured party did not have the opportunity to dispose of the capital. ${ }^{33}$

\section{THE POSITIVE EFFECTS OF THE COVID-19 PANDEMIC ON CONSUMERS IN THE COMPETITIVE FIELD.}

The COVID-19 pandemic has fundamentally changed the world as we know it. People live differently, buy differently, and in many ways think differently. Supply chains have been put to the test. Consumers around the world see products and brands from a new perspective.

The virus is transforming the consumer goods industry in real-time, rapidly accelerating long-term underlying trends in just a matter of weeks. Our research indicates that the new habits that are forming now will last beyond this crisis,

31 Article 101 and 102 (12) TFEU (Lisbon) related to the Practical guide on quantifying damages in actions for damages based on the violation

32 Castravet, D., Prejudice - essential condition of tortious civil liability in matters of unfair competition, Journal "Revista Național de Drept", 2016, no.11, p.58

33 Case C-271/91, Marshall Rec., [1993], par.31; Case C-295/04 - C-298/04, Manfredi Rec., [2006], par. 97 
permanently changing what we value, how and where we shop, and how we live and work. ${ }^{34}$

Even as this crisis continues to evolve, by exploring the changes that are happening now, we can take a look at what consumer goods companies should be doing today to prepare for the next day.

It must be recognized that COVID-19 is a health and economic crisis that has a lasting impact on the attitudes, behaviors, and purchasing habits of consumers. Consumer Staples companies can adapt to these changes by taking steps to respond, redefine and renew themselves to be even better positioned for the future.

One of the positive points linked to this epidemic is that brands are now even more determined to interest their customers. Each uses its charms to gain the favor of customers and keep it. This involves, for example, various purchase offers with free delivery wherever you are. Other tips such as the flawless availability of customer service or the enormous savings achievable on a purchase are used by companies. Just by comparing the offers, you realize the number of possibilities available to allow you to save. Obviously, production has also increased in several food areas.

The positive impact of the current health crisis is such that the time saved in transactions is considerably reduced since everything takes place on the internet. Tips and tricks are indicated by many brands to allow each other to spend this time in the best way. Some products have seen a significant reduction in their kilo price so that everyone can have access to them and go through confinement in optimal conditions. ${ }^{35}$

The other positive point is that promotions and discounts abound on the internet. Since traveling to a physical establishment is now difficult and risky, companies have adapted. Those who have an online platform to allow their customers to make purchases online are the ones with the most advantages. They offer promotions that are more frequent, more interesting, and that extend over longer periods.

Discounts on all products can be observed, as well as the multiplicity of tempting offers. Coupon codes are multiplying to allow you to shop for food and other products even with a limited budget. The promo code, therefore, allows you to

\footnotetext{
34 Coronavirus consumer behavior research [https://www.accenture.com/ca-fr/insights/consumer-goods-services/coronavirus-consumer-behavior-researchl, Accessed 20.06.2021

35 Comment les modes de consumation ont evolues depuis la crise sanitaire du Covid-19 [https://www. latribune.fr/supplement/comment-les-modes-de-consommation-ont-evolues-depuis-la-crise-sanitaire-covid-19-848256.html], Accessed 20.06.2021
} 
make significant savings. Sometimes, these good deals can even be combined for the greatest pleasure of consumers. So now is the perfect time to go to all your favorite brand sites to take advantage of these benefits with a promo code. ${ }^{36}$

Respectively, the trends of competition law have adapted to the requirements of consumers during the pandemic due to the possibility of using commercial practices that have contributed significantly to the development of the digital market, by offering the consumer to choose remotely and optimize time, although demand has decreased significantly concerning supply, especially in the sectors of public catering, clothing, etc.

\section{CONCLUSION}

In conclusion, we can mention that the right of consumers to be protected in terms of unfair competition requires the extension of current legislation to consumer economic protection to include consumers as subjects with the right to claim for illegal competition. This objective requires extending consumer access to justice to recover damages: legislation must strike a balance between the general interest of professionals, as competitors, and the individual interest of consumers, as individuals.

The Covid-19 pandemic took the entire planet by surprise in 2020. Almost all sectors of the economy were blocked, they aimed to improve the public health situation. From this perspective, we want to conclude that the general interest of a professional must be oriented to the individual interest of each consumer regardless of product group or type of service, regardless of the period, including overcoming the COVID 19 Pandemic which in 2021 has already become normality for the market economy.

Respectively, an essential role to balance the professional's goal of making a profit and the consumer's interest in obtaining a competitive and quality product belongs to the state by eliminating illegal competition, namely by coherent regulation of the competitive environment and consumer rights. The economic growth of a state is dependent on the well-being of society as a whole and of the consumer individually. The Moldovan legislature needs to review competition law concerning European judicial practice and to provide a wider field of redress for damage caused as a result of an act of unfair competition, namely by giving anyone the right to claim damages suffered.

36 op.cit. 


\section{REFERENCES}

\section{BOOKS AND ARTICLES}

1. Calais-Auloy, J., F. Steinmetz, Droit de la consommation, 5e éd., Dalloz, 2000

2. Cas, G., D. Ferrier, Traité de droit de la consommation, PUF, 1986

3. Castraveț, D., Damage - an essential condition of tortious civil liability in matters of unfair competition, "National Law Review", 2016, no.11, p.58

4. Fugaru, C., Anti-competitive practices and antitrust policies in the European Union. In: Journal of the Faculty of Economics and Business Administration West University of Timisoara, 2006, p. 110

5. Hémard, J., Droit de la concurrence et de la protection de certains consommateurs Gaz. Pal. 1971, 2, doctr. 575.;

6. Hémard, J., Droit de la concurrence et protection des consommateurs, Gaz. Pal. 1971, 2, doctr. 575 , p. 19

7. Oppetit, B., L'expérience française de codification en matière commerciale, D. 1990, chr. 6, note 21, p. 88

8. Paisant, G., Droit de la consommation, ed. Themis droit, PUF, Paris, 2019

9. Partnership and Cooperation Agreement between the European Communities and the Republic of Moldova, signed in Brussels on November 28, 1994, ratified by the Decision of the Parliament of the Republic of Moldova, No. 627 [1995] OJ L 181, pp. 0003 - 0048.

10. Plotnic, O., Craiu, N., Conceptions actuelles en matière des droits intellectuels en cumul avec la concurrence déloyale, Droit, humanité et environnement, Mélanges en l'honneur de Stéphane Doumbé-Billé, 1 re édition Larcier (France), 2020, p.249-262

11. Py, P., Droit du tourisme, Dalloz 15 Novembre 1996

12. Rousseau, J.J., Les Integrales de Philo, Du contrat social, Livres I a IV, notes et commentaires de J.F. Braunstein, Nathan, Paris, 2002

\section{COURT OF JUSTICE OF THE EUROPEAN UNION}

1. Case C-199/11 European Community / Otis NV and others, [2012], p.I-5161

2. Case C-271/91, Marshall Rec., [1993], p.1-4367

3. Case C-295/04 - C-298/04, Manfredi Rec., [2006], p.I-6619

4. Case C-360/09 Pfleiderer, Rep., [2011], p.I-5161

\section{ECHR}

1. Association Agreement between the Republic of Moldova and the European Union, No. 112/2014. Official Gazette, No.185-199/2014

2. European Commission Joint Staff Working Document Implementation of the European Neighbourhood Policy in the Republic of Moldova: Progress in 2012 and recommendations for action. SWD, 2013, No. 80 final, 20 p.

3. Republic of Moldova - European Union Action Plan for the period 2005-2007, International Treaties No.38/2006 
4. Treaty on European Union [2008] OJ, C 115

5. Treaty on the Functioning of the European Union [2012] OJ, C 326/47

\section{EU LAW}

1. Council Directive 2005/29 / EC on unfair business-to-consumer commercial practices in the internal market and amending Council Directive 84/450 / EEC, Directive 97/7 / EC, 98/27 / EC and 2002/65 / EC [2005] OJ L 149/2005

2. Council Directive 2011/83 / EU on consumer rights, amending Council Directive 93/13 / EEC and Directive 1999/44 / EC of the European Parliament and of the Council and repealing Directive 85/577 / EEC of the Council and Directive 97/7 / EC of the European Parliament [2011] OJ L 304/2011

3. Council Directive 2014/104 / EU on certain rules governing actions for damages under national law in the event of infringements of the competition laws of the Member States and of the European Union [2014] OJ JO L 349/2014

\section{LIST OF NATIONAL REGULATIONS, ACTS AND COURT DECISIONS}

1. Constitution of the Republic of Moldova. Official Gazette of the Republic of Moldova, No.1/1994

2. Law on competition of the Republic of Moldova no. 183/2012. Official Gazette No.193$197 / 2012$

3. Law on consumer protection no.105-XV from 13.03.2003 of the Republic of Moldova, Official Gazette no.126-131/507/2003

\section{WEBSITE REFERENCES}

1. Comment les modes de consumation ont evolues depuis la crise sanitaire du Covid-19 /https:// www.latribune.fr/supplement/comment-les-modes-de-consommation-ont-evolues-depuisla-crise-sanitaire-covid-19-848256.html], Accessed 20.06.2021

2. Commission European, act for the Consumers. Why is competition policy important for consumers? [https://ec.europa.eu/competition-policy/consumers/why-competition-policy-important-consumers_fr], Accessed 20 June 2021

3. Coronavirus consumer behavior research [https://www.accenture.com/ca-fr/insights/consumer-goods-services/coronavirus-consumer-behavior-research], Accessed 20 June.2021

4. Practical guide on quantifying damages in actions for damages based on the violation related to the article 101 and 102 (12) TFEU (Lisbon), [https://ec.europa.eu/competition/antitrust/ actionsdamages/quantification_guide_en.pdf], Accessed 5 June 2021

5. Sagan, A., Mask makers raise prices as material, labour costs rise amid pandemic, June 2020, [https://www.mromagazine.com/2020/06/15/mask-makers-raise-prices-as-material-labourcosts-rise-amid-pandemic/], Accessed 5 April 2021 